\title{
DISTRIBUTION OF ENGLISH TEXTILES IN THE SPANISH MARKET AT THE BEGINNING OF THE $18^{\mathrm{TH}}$ CENTURY*
}

\author{
NADIA FERNÁNDEZ-DE-PINEDO ECHEVARRÍA
}

Universidad Autónoma de Madrid ${ }^{\text {a }}$

EMILIANO FERNÁNDEZ-DE-PINEDO FERNÁNDEZ

Universidad del País Vasco ${ }^{\mathrm{b}}$

\begin{abstract}
This article examines the marketing and distribution of foreign fabric, predominantly English, in the northern sub-plateau of Spain at the beginning of the $18^{\text {th }}$ century using information from a fiscal source. The official tax record used in this study was a specific and special tax levied on cloth imported from countries with which Spain was at war. The details of this tax shed more light on a hotly debated topic with respect to transport and

* Received 26 June 2012. Accepted 9 April 2013. This work was co-financed by MICINN HAR 2008-04978/His and HAR 2012-35965/His and the Basque Government (Gobierno Vasco/Eusko Jaurlaritza, Grupo de Investigación consolidado IT337-10). A preliminary version was presented at the Pasold Research Fund and Chord Joint Conference (Session: Distribution networks for textiles and dress, c. 1700-1945) at the University of Wolverhampton in September 2010. The authors are grateful to all the participants for their suggestions and comments. They would also like to thank Fernando Esteve, Ernesto López Losa, Santiago López, Patricio Sáiz and Philipp Sykas as well as the referees of this journal. Any errors remaining in the text are our responsibility.

a Senior Lecturer, Universidad Autónoma de Madrid, Dpto. Análisis Económico: Teoría Ec. e Historia Ec., Facultad de CC.EE. y EE. - Cantoblanco, 28049 Madrid, Spain. Telephone: +34 914972688. nadia.pinedo@uam.es

b Full Professor, Universidad del País Vasco, Dpto. Historia e Instituciones Económicas, Facultad de CC.EE. y EE, Lehendakari Aguirre, 83, 48015 Bilbao, Spain. Telephone: +34 946013724 emiliano.fernandezdepinedo@ehu.es
\end{abstract}


networks in modern Spain and make it possible to analyze and quantify the physical volume as well as the value and the destination of textiles.

Keywords: taxation, distribution, english textile, trading enterprise, Spain, $17^{\text {th }}$ century

JEL Code: N7, L81, L67, R12

\section{RESUMEN}

En este trabajo se analiza la comercialización y distribución de tejidos extranjeros en la sub-meseta norte de España a comienzos del setecientos a través de una fuente fiscal que nos permite matizar ciertos aspectos relacionados con la demanda de textiles. La fuente utilizada en este trabajo es un impuesto que se cobraba sobre los textiles importados en tiempos de guerra y que recoge quien enviaba la mercancía, el receptor de la misma, el transportista, el tipo de tejido, su valor fiscal, la cantidad así como el impuesto extraordinario pagado que iba a la tesorería real. Los resultados de este estudio permiten analizar en profundidad por lo tanto las redes de distribución y el tipo de tejidos ingleses que se demandaban.

Palabras Clave: fiscalidad, tejidos ingleses, transporte, arriería, españa, siglo XVIII

\section{INTRODUCTION}

Despite the significant body of literature, which has accumulated on the topic of the consumption of textiles in modern times and on the relationship between commercialization and trust, economic historians still have some gaps to fill regarding consumption and distribution patterns in the $18^{\text {th }}$ century. The current work attempts to contribute to a new approach to the topic.

Our case study delves deeper into the main features of the marketing of manufactured textile products and draws some key conclusions in an attempt to identify trends in market distribution. In a first attempt at filling the gap, we analyze the source in order to test the validity of the data used in this article. Our primary sources of data are the records found in the Archivo General de Simancas (Spain) and correspond to a fiscal source that calculates the tax payable on foreign textiles when imported into Spain. The documents to carry out this study provide not only qualitative but, more importantly, quantitative information, which allows us to establish statistically the type of cloth, mostly from England, imported mainly through the Bilbao port, the specific geographical location of the re-sales (Madrid, capitals of provinces 
and rural areas) and the transporters and their possible kinship, linguistic and/or geographical connections between sellers and buyers.

The paper is organized around two objectives. The first is to determine the evolution and origin of English fabric consumption patterns during the $18^{\text {th }}$ century. According to the source, new draperies were not the only ones demanded in early $18^{\text {th }}$ century Castile. The data available indicate that the fabric import flow to Castile was overwhelmingly centered on mid-quality cloth.

The second objective is to identify the factors that affected distribution and commercialization modes in modern times. The characteristics and extension of the Castilian market appear to be much more complex than previously recognized in certain historiographical sectors. According to them, the Castilian economic crisis provoked the macrocephaly of Madrid, concentrating administrative activities and the local nobility and, therefore, a greater proportion of consumption, in detriment to other urban centers (Torras and Yun 2003, pp. 27-28). However, the capitals of provinces (provincial towns), according to Ringrose, did not appear to affect the model of transport demand - «these provincial towns did not greatly influence the over-all pattern of demand for transport» ${ }^{1}$. While it is true that Madrid was an important centre of consumption, we were able to ascertain that other towns also absorbed large quantities of manufactured goods, including imported and domestic textiles. In light of these findings, we have to consider the relative geographic dispersion of this demand as one of the characteristics of $18^{\text {th }}$-century Castile.

We must point out that merchandise of great value, but not weighing very much, has been the object of particular attention in recent years, as seen in the works of Florence Fontaine, Jan de Vries, Jaume Torras and Bartolomé Yun or Ramos among others (Muset i Pons 1997; Fontaine 1999, 2008; Torras and Yun 2003; Denzel et al. 2011; Ramos 2010). A long-standing presumption in this literature has been that the marketing of certain manufactured products appears to be frequently linked to the development of socio-economic networks based on local connections of trust such as family, religion, geography or language and security, striving at the same time for low freight and intermediation costs (Hamilton 1947; Ringrose 1970; Madrazo 1981; Baker and Gerhold 1993; Greif 1994; Alexander and Akehurst 1998; Botticini and Eckstein 2007; Guiso et al. 2008; Barro and McClearly 2006; López Losa 2013). Having examined the documentation, there is no evidence for a network based on kinship or geography linking the importer to the carrier and the consignee of the merchandise. Apparently, the basis of this network structure was trust (among others, Coleman 1990; Cox 2004; Fukuyama 1995; Gambetta 1988; Granovetter 1973; Greif 1993) and efficiency.

Trust has recently been studied from the standpoint of economic sociology, behavioral economics, organization theory and games theory

1 Ringrose (1970, pp. 8, 26). A reinterpretation of the role played by Madrid and the periphery in Grafe (2012, Ch. 8). 
(Dasgupta 2000, p. 49). As Coleman suggested, trust - defined as credibility, integrity, loyalty, knowledge and efficiency - is generated by three mechanisms: interpersonal contact, reputation or institutional context (Coleman 1990; Dasgupta 2009). In this sample, each carrier's behavior was recorded after each transaction, so potential future employers-customers would know that carrier's history and therefore reputation and so could hire them or not. As shown by game theory, trust arises from the indefinite repetition of exchanges between the same parties, or is an output of a network belonging to the same social or religious milieu. Avner Greif has shown that networks of Jewish, Christian or Arab merchants allowed trade through the Mediterranean in the absence of a mechanism for legal enforcement of contracts (Greif 1993, 2006; Edwards and Ogilvie 2012, pp. 421-444). In our case study, however, instead of a distribution network focused on very specific communities of individuals or Diaspora merchants, we have a network within a country whose roots are in the Middle Ages, although its economic mechanisms are not archaic. Obviously, the economic infrastructure had to be based on a spontaneous network of trust, but not necessarily by definition in confidence based on family, local or linguistic ties ${ }^{2}$.

If there are three sources of trust - family, interests, or norms and values that generate trustworthiness and predictability - what we observe in this research is the last one (Adler 2001, p. 218). Neither language nor kinship nor the closeness of neighborhoods seems to have been an influence, in this case study, in choosing the carrier. Commitment between carriers and other agents in the Castilian market was generated year by year within a solid network based on honest behavior and satisfactory work, but was not linked, as shown in the following pages, with other factors such as family or language. These mechanisms reinforce effectiveness. As will be shown, there did not even appear to be ties of these characteristics between the dispenser (from Bilbao or Vitoria) and receiver (any merchant or shopkeeper from a Castilian town). The choice was based on price, quality of service and security of payment; that is, purely economic considerations. Undoubtedly, this work provides new perspectives in understanding how pre-industrial distribution and consumption networks conducted their business in southern Europe.

\section{TEXTILE DEMAND AND THE ROLE OF THE PORT OF BILBAO AS A CENTER OF DISTRIBUTION}

\subsection{Imports of British fabrics}

Throughout the $17^{\text {th }}$ century, England and Holland consolidated the use of «new draperies» made of woollen cloth, sometimes with a mixture of

2 Axelrod (1984), Lee (2011, p. 9). On family and market transactions, see Ben-Porath (1980, p. 2 and 5) and also Valdaliso and López (2006). 
lightweight fibers, of average quality, with new designs, attractive and cheaper, using indigenous raw materials in the case of England and materials brought in from nearby in the case of Holland (Coleman 1969, pp. 417-429; Wee, van der 2002, pp. 452-461). In the second half of that century, Holland experienced a regeneration of the market for luxury cloth, which included the famous lakens made with Spanish merino wool. These changes in the types of cloth used had a significant influence on Spanish artisan textiles and on the demand for Castilian cloth. From the beginning of the $17^{\text {th }}$ century, the Castilian Courts and well-documented reformers ${ }^{3}$ pointed out that the competition resulting from cheap imported textiles of average quality was, in effect, eliminating Castilian and Andalusian products of the same quality (cloth with a thread count of between eighteen, dieciochenos and twenty, veintedosenos ${ }^{4}$ ) from the domestic market ${ }^{5}$.

This process continued until Castilian and Andalusian (from Córdoba, Los Pedroches, Úbeda, Baeza) textiles of lower and average quality almost disappeared, or severely declined in the case of Segovia, having been replaced by textiles closer to the new draperies. England, Holland and France competed to supply textiles to the Castilian market; however, their products and interests were marked by certain nuances. All of them were interested in maintaining a positive trade balance in order to obtain American silver or to facilitate trade with the Far East. Holland was able to provide linen, silk and wool textiles of generally very good quality. Both southern Spain and the West Indies were major consumers of linen, and, to a much lesser degree, of quality wool cloths. Only a very small proportion of the Spanish nobility was able to acquire Dutch lakens. For the United Provinces, Spain and the West Indies were major markets for their linen textiles. France also provided this type of textile and, when engaged in trade or contraband with Spain or its possessions, targeted the Seville-Cadiz-West Indies market. French and Dutch rivalry centered around linen, and to a lesser degree, silk textiles. England, however, only competed with cheaper woollen textiles of average quality, very little in demand in India, having Castile as their main market due to weather conditions ${ }^{6}$.

${ }^{3}$ Memorial in Felipe IV times, reproduced in Larruga (1793, p. 132). Among arbitristas (reformers) especially Damián de Olivares «Respuesta de Damian de Olivares a un papel que ha salido sin autor, que se intitula advertencias para la prohibición de las mercaderias estrangeras, que dize da causas porque no de deuen prohibir por ley absoluta, y pregon escandaloso. Dirigida al Excelentisimo Señor Conde de Oliuares», Madrid 20 $0^{\text {th }}$ of February 1622 (B.N., R-37.064). Vilar (1991, pp. 99-166).

4 eno indicates the count of yarns (2.600) employed for the warp.

5 The Spanish tax of 1680 enables us to define the relative quality of English and Castilian textiles. The Alconcher cloths, black or white, between 14 and $15 \mathrm{rs}$./varas, the perennial up to 12 rs./vara, the Dutch cloths (probably lakens) and English (probably broadcloths) at 44 rs./vara. The Segovia shrunken cloths at $25 \mathrm{rs}$./vara, the Segovian 20 eno cloth around $24 \mathrm{rs}$./vara, the black $20 \mathrm{eno}$ at $30 \mathrm{rs}$./vara, the best $22 \mathrm{eno}$ at $46 \mathrm{rs}$./vara and the best $24 \mathrm{eno}$ at $50 \mathrm{rs} . / \mathrm{vara}$.

${ }^{6}$ See Fisher (1950, p. 30). Davis (1954, pp. 150-163) pointed out that «exports are still dominated, overwhelmingly, by woolen cloths (L 2,772 th. out of L 2,815 th. textile exports; almost three-quarters of all exports to Europe)». 
After the Münster Peace Treaty of 1648 had been signed between the United Provinces and the Spanish monarchy, Castilian merino wool enjoyed a good reception in the Dutch luxury draperies market (Bilbao and Fernández de Pinedo 1994, pp. 101-114). During the period of Castilian economic decline, the industry of migrating herds of sheep made its recovery thanks to foreign demand. Plausibly, due to the control of credit, creating the capability of acquiring merino wool from smaller producers as well as larger sheep farmers before the sheep-shearing process, both local and foreign dealers from Bilbao took control of the double circuit of raw materials export and textile import. Therefore, during a general urban decline in Spain, the population of Bilbao expanded.

The port of Bilbao had become the hub of extensive commercial activity, reaching as far as Logroño in the Ebro Valley, Valladolid along the Duero River and Madrid in the south. Undoubtedly this network went as far back as the Middle Ages, and was reinforced by the reactivation of wool exports in the second half of the $17^{\text {th }}$ century. This article clearly outlines for the first time the extent of this network and its importance in the distribution of foreign textiles, mostly from England, throughout Castile.

Sir Josiah Child estimated around 1692 that England was exporting $\sim 775,000$ units of items such as new draperies in addition to broadcloth, with 39 per cent of them going to Spain (Sir Josiah Child 1693, p. 10). For the English textile industry, Spain was a substantial market, as we describe in detail in this paper. The production of new draperies, consisting of lighter fabrics in great demand in southern Europe, predominated in East Anglia, as well as medley clothes in the West Country, along with a progressive increase in contracts in the dyeing and finishing industry as a result of protestant craftsmen and merchants, escaping war and religious prosecution on the Continent, relocated here. Specialization took place, favoring some production centers. However, these textiles were not the only ones demanded in early $18^{\text {th }}$-century Castile, according to our data. Although there appears to be a data gap during the war of Spanish Succession between 1701 and 1713, the data available indicate that fabric continued to flow into Castile, and was overwhelmingly centred on mid-quality cloth.

\subsection{Network set up from Bilbao}

Taxes - direct, indirect or special levies in wartimes - allow us to better appreciate how production, distribution and consumption operated, as well as the networks that were forming. The two elements that will permit us to unravel this situation and offer a much broader and clearer view of what type of British fabrics were consumed and distributed in Spain in the early $18^{\text {th }}$ century are precisely a war and a tax.

As a matter of fact, wartime taxes generated vast quantities of revenue in Modern Times. Between the years of 1710 and 1714, Philip V levied a special 
tax on imported fabrics from England and Holland because both countries opposed the Bourbon candidate's occupancy of the throne left vacant by the death of the last king of the Habsburg dynasty (Charles II). Philip V had banned the import of products from those countries in the first place. However, fiscal necessities and perhaps the Castilian shortages of certain textile products forced him to lift the ban gradually. First, he allowed the entry of products of «illicit trade», except wool and silk fabrics from England and Holland, provided that they came from friendly or neutral ships and that they paid a 7 per cent "penalty» in addition to the normal duties. Later, these constraints disappeared but the fabrics from England and Holland incurred a 10 per cent penalty. Of that percentage, half was given to the tenants of customs duties and the other half to the king. This tax is the source of the records used in this study, from which the following information regarding the merchandise is obtained: the sender, the recipient, the transporter, the fabric type, the quantity and the special tax that was paid to the royal treasury. The 10 per cent value was established based on a prior assessment of the fabrics, which did not change between the years of 1710 and 1714 in which the tax was enforced ${ }^{7}$.

We found fabrics that were imported through the port of Bilbao and introduced to the rest of the monarchy and paid their duties in the inner customs of Valmaseda, Orduña and Vitoria. Of the three customs offices, the busiest one recorded was Valmaseda, followed by Orduña, with Vitoria far behind. Fabrics dispatched to territories between Toledo and Madrid, the southern slopes of the Cantabrian Mountains and Vitoria passed through the first two customs offices. Although transiting goods were destined for Madrid, a significant fraction of the fabrics was destined for the areas of the upper valley of the Ebro, the valley of the Duero and nearby areas. While destination sites located further south can occasionally be found, in general the limit reached by the imported manufactured goods from the port of Bilbao appears to be in Toledo, in the upper valley of the Ebro, the Duero valley and the Iberian System, in Logroño and in Soria, as shown in Map 1.

Using the information provided by the customs authorities, we can obtain: the sender, the recipient, the transporter, the fabric type, the quantity and the special tax paid to the royal treasury, which was proportional to the value of the material.

As the information that has been preserved is not complete, because in some customs offices information for whole years was not kept, we have

7 The Royal Order is dated December 27, 1709 and the supporting documentation can be found in the Archivo General de Simancas (hereafter A.G.S.), Tribunal Superior de Cuentas, files 854 and 855. Actually this Royal Order (December 27, 1709) only affected English products because a Royal Order dated December 3, 1710 forbade the importation of Dutch fabrics. This was in retaliation for the Geertruidenberg breaking of peace negotiations. 


\section{MAP 1 \\ DISTRIBUTION OF FOREIGN TEXTILES IN CASTILE THROUGH THE NORTHERN PORTS OF SPAIN (IN REALES VELLÓN)}

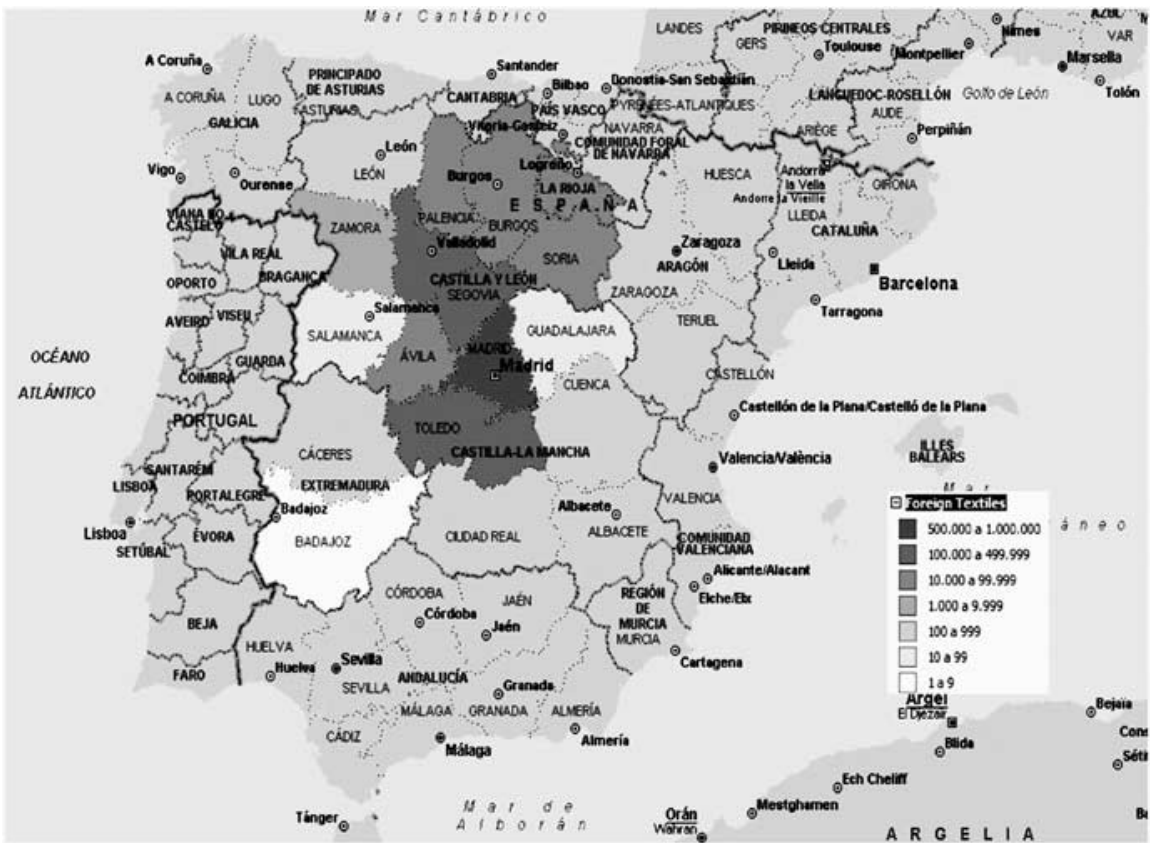

standardised the data by reducing the information to an annual average. In this way, the figures accurately reflect the annual average characteristics of fabrics imported through the port of Bilbao and introduced into the rest of the monarchy between 1710 and 1714 .

The fact that these data come from war years could raise at least two limitations that throw some doubt on the source. First, even though it was wartime the only year in which battles could have altered the movement of merchandise and their distribution, especially in Madrid, was $1710^{8}$. The war, however, had other economic effects through taxation requirements ${ }^{9}$. In some cases, the royal treasury tried to reduce some costs by suspending the payment of grants, pensions and other allowances or by delaying the payment of wages to the bureaucracy, which reduced the income of certain privileged groups. More generally, however, the war meant a rise in tax levies, which affected the

${ }^{8}$ The year 1710 was particularly adverse for the Bourbon armies in Spain and primarily affected north-eastern Spain.

9 Spain was at war in a range of 47-92 per cent of years in some centuries (Tainter 2000, p. 29). 
entire population ${ }^{10}$. In addition to the regular taxes, some of which rose - like the cientos, special taxes were also required: in 1710 a "donation» of 12 rs./household head; in the following year, $100 \mathrm{rs}$./household head; in 1712 another 40 rs./household head; and charges continued in 1714 (Canga Argüelles 1968, pp. 118-119; Kamen 1975, p. 223 and following; Fernández-de Pinedo 2012, pp. 101-111). These taxes must have had effects on demand, promoting the wartime necessities of weapons, uniforms and food for soldiers and horses, but diminishing civil demand. The fact that distribution in 1710 could have been altered by the battles and the economic effect on demand caused by the war suggests that the demand for fabrics must have been below normal.

\section{IMPORTED TEXTILES}

\subsection{Fabric types and origins}

During these war years (1710-1714), 192,563 m/year (some 230,338 varas/ year) of fabric of different widths were imported through the port of Bilbao. At least, these are the amounts that were legally imported and on which the corresponding taxes were paid. Although the source referred to the tissues imported from England and Holland, it is noteworthy that 90 per cent of linen fabrics came from Holland, while only 10 per cent of woollen cloth was of Dutch origin. In fact, the Royal Order of December 27, 1709 only affected English products because a Royal Order dated December 3, 1710 forbade the importation of Dutch fabrics. This is why we only focus on the study of English cloth from that time onwards. Obviously, Dutch linen fabrics imported through England were re-exportations, and were illegal imports in Spain.

Although their source and boundaries are not exactly the same, during the $17^{\text {th }}$ century, there appears to have been a significant shift in the types of fabric imported into Castile. In the years 1615-1616, Castile imported mainly serge and lilac (50 per cent of imports corresponded to this fabric), sempiternals or perpetuanas ( 8 per cent) and baize $(6 \text { per cent })^{11}$. The situation started to change at the end of this century when, according to the fabrics introduced through the port of Cádiz in 1685 (Girard 1951), bays and perpetuanas represented more than 60 per cent of imports as indicated in Table $1^{12}$.

10 Issues on war, state and taxation among others: Kennedy (1989), Tilly (1975), Gunn et al. (2007), Bonney (1999), Hart (1995), Hart et al. (1997), Tracy (2002), Parker (1979), J. de Vries and A. van der Woude (1997), Dickson (1967), Neal (1990).

11 Castile includes New Castile, Andalusia and Extremadura. Fernández de Pinedo (2004, pp. 464-465). For a previous period, see Childs (1978, 2003).

12 «Top-quality scarlet cloth was also available from England and in the late $15^{\text {th }}$ century Castilian merchants took about 60 per cent of England's total scarlet cloth exports. Spain, both north and south, was a very important market for English cloth by that time, and in the 1480s Spanish merchants, almost all from Burgos and the Basque Provinces, took 10-15 per cent of England's total cloth exports, mainly through London» Childs (2003, p. 61). 
TABLE 1

ENGLISH FABRICS IMPORTED THROUGH THE PORT OF CÁDIZ IN 1685

\begin{tabular}{|l|c|c|}
\hline Type of fabric & Value in French pounds & $\%$ \\
\hline Bayettes/bay & 280,000 & 43.55 \\
Étamines/etamine & $80 / 100,000$ & 14.00 \\
Bas de soye/silk stocking & 12,000 & 1.87 \\
Bas de laine première/woollen stocking, first quality & 15,000 & 2.33 \\
Bas de laine seconde/woollen stocking, second quality & 15,000 & 2.33 \\
Bas de laine troisième/woollen stocking, third quality & 10,000 & 1.55 \\
Sempiternes/perpetuanas & 80,000 & 12.44 \\
Sempiternilles/thinner perpetuanas & 40,000 & 6.22 \\
Escarlates/scarlets & 25,000 & 3.89 \\
Bombazins/Bombasine & 18,000 & 2.80 \\
Draps d'Angleterre/English woollen cloth & 8,000 & 1.24 \\
Toiles de coton/cotton cloth & 50,000 & 7.78 \\
\hline Total & $633 / 653,000$ & 100 \\
\hline
\end{tabular}

Source: Mémoire générale sur le commerce qui se fait aux Indes Occidentales par Cadiz... Mémoire dit de Patoulet, enquête de c. 1685. Morineau (1985).

At the beginning of the $18^{\text {th }}$ century, at least with respect to fabrics imported from England into Bilbao, the data confirm this trend.

Serge was insignificant, representing $<1$ per cent $(0.44 \%)$, and three other fabrics in particular had a practical monopoly on imports as shown in Table 2. In physical measurements (varas), the most imported fabric was perpetuanas/sempiternals (42 per cent), followed by bays (39 per cent) and callimancoes/calamanco (11 per cent). In total, these three fabrics were responsible for 94 per cent of the value of imports, due to the higher prices of baize, and for 92 per cent of their physical volume.

The light weight of the cloths, which were the most expensive fabrics, is surprising, as is that of the canvasses. French support for the war probably had a positive impact on their exports while showing the low weight of the cloth and linen fabrics exported directly from England and Holland (Girard 1951). Consequently, such fabrics were probably brought mainly via France. These data fit fairly well with the English textile exports statistics collected by Elizabeth Boody Schumpeter regarding the importance of baize, wools and serge among the woollen clothes exported by England in the same period and the small quantity of the linens specifically sent to southern Europe $^{13}$. In contrast, the statistics on English exports during the same time

${ }^{13}$ Schumpeter (1960, tables XIV, XXXIV, XXXVI, XXXVIII, XXXIX y XLI). 
TABLE 2

IMPORTED FABRICS IN VARAS AND MRS. ANNUAL MEAN OF THE THREE CUSTOMS, 1710-1714

\begin{tabular}{|c|c|c|c|c|}
\hline Type of fabric & mrs. SM & $\%$ mrs. SM & $\%$ Varas & Varas \\
\hline Woollen stuff & 44,317 & 1.79 & 3.39 & $5,509.55$ \\
\hline Barracan & 3,500 & & & 448 \\
\hline Bay & $1,128,428.30$ & 45.62 & 39.21 & $90,322.38$ \\
\hline Calamanco & $217,954.80$ & 8.81 & 11.13 & $25,641.80$ \\
\hline Brussels camlet & 178.4 & & & 5.25 \\
\hline Serge-like shaloon & 2,250 & & & 270.00 \\
\hline Wool camlet & 600 & & & 100.00 \\
\hline Wool damask & 275.4 & & & 50.40 \\
\hline Scarlet cloth & 44,530 & 1.8 & 1.93 & 4,453 \\
\hline Silk stuff & 642 & & & 100.80 \\
\hline Serge-like woollen stuff & $7,119.45$ & 0.29 & 0.44 & $1,007.35$ \\
\hline Quilted stuff & 2,650 & & & 318.00 \\
\hline Silk stuff & 367.2 & & & 10.80 \\
\hline Plush shag & 1,212 & & & 101.00 \\
\hline Damask & 1,292 & & & 266.00 \\
\hline Wool flannel & 1,125 & & & 252.00 \\
\hline Canvas & $11,661.20$ & 0.47 & 1.5 & $3,461.26$ \\
\hline Cloth & $18,668.80$ & 0.75 & 0.14 & 323.20 \\
\hline Double camel hair & 741 & & & 67.40 \\
\hline Serge & $5,318.40$ & & & 557.60 \\
\hline Sempiternal & 978,209 & 39.55 & 42.05 & $96,863.40$ \\
\hline Fine baize & 300.00 & & & 36.00 \\
\hline Taffeta & 2,070 & & & 172.50 \\
\hline Total & $2,473,410.30$ & & & $230,337.68$ \\
\hline
\end{tabular}

mrs. $=$ maravedises.

Notes: One vara is equivalent to $0.836 \mathrm{~m}$. Between 1710 and $1714,192,563 \mathrm{~m}$ were imported.

Source: A.G.S., Tribunal Superior de Cuentas, files 854 and 855.

(albeit referring to southern Europe) indicate significant exports of long and short cloths, which do not appear in the data for Spain. Our source suggests that there was an important change in fabrics being imported into Castile throughout the $17^{\text {th }}$ century ${ }^{14}$.

${ }^{14}$ We have to thank Philip Sykas for his comments, help with fabric names and also for providing some of the sources consulted. See Nemnich 1799; Cox and Dannehl (2007) and Sykas (2009). 
TABLE 3

FABRIC RATINGS ACCORDING TO THE TYPE OF FABRIC

\begin{tabular}{|l|c|l|c|}
\hline Type of fabric & mrs./vara & Type of fabric & mrs./vara \\
\hline England scarlet cloth & 170 & Wool callimanco & 17 \\
Holland and England cloth & 102 & Barracan & 15.63 \\
Brussels camlet & 68 & Painted serge & 14 \\
Silk stuff & 68 & Wool stuff & 14 \\
Wool damask & 28 & Fine wool stuff & 12 \\
Bay & 25 & Dutch linen & 12 \\
Serge & 25 & Wool camlet & 12 \\
England taffety & 24 & Thin linen & 10 \\
Plush shag & 24 & Damask & 9.71 \\
England camel's hair & 22 & Wool flannel & 8.93 \\
Woollen stuff & 20 & White German linen & 7 \\
Sempiternal/perpetuanas & $20-21$ & Ecru lace linen & 6 \\
England fine scarlet cloth & $18-20$ & Thin linen & 6 \\
\hline
\end{tabular}

Source: A.G.S., Tribunal Superior de Cuentas, files 854 and 855.

To assess the tax payable, fabrics were evaluated by varas or pieces; the source suggests that the tax applied to them was equivalent to 10 per cent of their value. Besides their commercial accuracy, these ratings allow us to classify tissues based on their likely quality. Excluding flax, linen and silk-stuff or taffeta (which represent 9 per cent overall), fabrics can be grouped into three basic categories: expensive, medium-priced and cheap as shown in Table 3.

- Expensive, basically cloths (ranging from 102 to $170 \mathrm{mrs} . / \mathrm{vara}$ ).

- Medium-priced fabrics such as perpetuanas, damask wool, plush shag, camel hair (Turkish yarn), bays (ranging between 20 and $25 \mathrm{mrs}$./vara), which were the most imported. Bays were a tissue of loose and thin wool used by the clergy in their clothes and among women for blankets and other uses. The best fabrics were less expensive than the Segovian fabrics. Perpetuana was a tightly woven fabric with sturdy consistency, used by poor women ${ }^{15}$. These intermediate fabrics were the most requested.

15 The best Spanish flannels, those from Segovia, were valued slightly below the 20no cloths of the same city, at the end of the 17th century. However, there were very cheap baize like those from Molina and Sigüenza. 
- The rest were cheap, ordinary fabrics (below $20 \mathrm{mrs} . / \mathrm{vara}$ ) such as worsted, wool camlet ${ }^{16}$ (except for Brussels camlet that must be included in intermediate quality fabrics), canvas or callimancoes ${ }^{17}$.

Imported woollen clothes accounted for $<1$ per cent of the total value. In contrast, the intermediate fabrics, baize, perpetuanas and so forth accounted for more than 85 per cent, and other fabrics accounted for the remaining 4 per cent. All the evidence indicates that the majority of imported fabrics were of medium quality and that they were not manufactured with merino wool. If we compare these data with those offered by Morineau in Table 1 concerning English textiles introduced via the port of Cadiz, we observe the same trend regarding the importance of the perennial (Morineau 1985, pp. 334-336).

Thus, the Spanish textile industry could not compete only in the realms of expensive fabrics and quality cloth but also had to compete in medium quality fabrics.

Whereas in 1600 , the cloth export trade had been concentrated in London, in 1700 «trade became less concentrated both because of the major growth of cloth exporting from provincial ports and because of the inflow of non-professional London and provincial merchants into the unregulated trades to America and the Iberian Peninsula» (Nash 2005, p. 113).

Concerning the origin of the fabrics, we can say that the exact geographical origin is not always clear in the source. However, there is strong evidence that most came from England - in fact, we have no doubt in the case of 44 per cent of all imports whose origin was explicitly specified as English. We are certain in the particular case of callimancoes, which all came from England, presumably from Lavenham (Wilson 1960, p. 211); in the case of 27 per cent of the perpetuanas, and with regard to bays, 64 per cent came specifically from Colchester. In the source, this town is listed as Alconcher, which obviously refers to Colchester, and not the Portuguese town of Alconcher. At the beginning of the $17^{\text {th }}$ century, "Colchester was linked administratively with its near neighbor Ipswich, but its cloth trade was essentially different, being more akin to that of Sandwich with which it may be conveniently treated. Both these ports exported mainly new draperies-bays, says and, later in the period, serges and perpetuanas to France and Spain and also to the Low Countries...» (Stephens 1969, p. 239).

\footnotetext{
16 «The high values of fine woolens and camlets, associated with high quality, help to explain why these types of cloth maintained their position better than cheaper types» Wilson (1960, p. 219).

17 In the evaluations of the tissues to pay the tax, the «white baize from Alconcher» (England), the «black baize from Alconcher» or simply the «baize from Alconcher» were always assessed at $25 \mathrm{mrs}$./vara; only the «ordinary baize from Alconcher» was valued at $20 \mathrm{mrs}$./vara. Something similar occurred with sempiternals (whether they be printed, worked, painted or plain sempiternals), valued at $20 \mathrm{mrs} . /$ yard. Regarding colors, see Schneider (1978).
} 
In fact, bays, says, serges, sempiternal, callimancoes and other fabrics of lesser importance were products of the new draperies, which had been developed since the late $16^{\text {th }}$ century, and were distributed throughout Spain after the peace of 1604 (Fisher 1950, pp. 151-161; Fernández de Pinedo 2004, p. 462). By 1700, their products were among the most exported fabrics from England. In East Anglia, the main centres of production were Norwich, specialized in stuffs, fine worsted, mixed worsted and bombazines, followed by Colchester ${ }^{18}$. This city had specialised in bays, says - a fabric also manufactured in Suffolk and Sudbury - and perpetuanas made with English wool, and since the early $18^{\text {th }}$ century, also with Irish wool ${ }^{19}$. They were products of the new English drapery which by this time had ceased to be a novelty $^{20}$. It is usually argued that because they were light fabrics, they adjusted well to the Mediterranean weather. Given the winter temperatures of the Castilian plateau, this is not a very good argument.

Indeed, at the beginning of the $18^{\text {th }}$ century, at least with respect to fabrics imported by Bilbao and those from England in varas, serge was insignificant $(0.44 \%)$, and perpetuanas were the most imported fabric (42 per cent), followed by bays (39 per cent). It is surprising that serge, which represented the highest percentage of woollen exports in England in 1700, had any relevance in northern Spain. It seems to be a question of fashion (Wilson 1960, p. 220). Callimanco, not identified in the early $17^{\text {th }}$ century, accounted for 11 per cent. It is clear that there had been a change in the demand for fabrics in Castile.

\subsection{Consumption of imported fabrics}

In accordance with these facts, the importation of fabrics from England and Holland in the northern sub-plateau of Spain was predominantly of medium quality. Let us see if there is any difference between the consumption of the different regional areas. There is no absolute certainty that the fabrics destined for the capital of a province were sold and consumed in that city. They could have been forwarded to rural markets and fairs, or wealthy peasants could have visited the capital to stock up on certain manufactured goods, including textiles. Hence, the division between the capital and elsewhere in the province must be interpreted with caution.

\footnotetext{
18 Wilson (1960, p. 211), Smail (1999, p. 16), Sykas (2006). On the decline of the textile industry in Norwich and Essex, see Burley (1958, pp. 289-301) and Prichard (1950, pp. 371-377).

19 Fisher (1950), Wilson (1960, pp. 209-221), Browden (1962, pp. 41-43, 44, 53 and pp. 66-67), Coleman (1969, pp. 417-429). A vision not generally accepted in Kerridge (1985). For tissue types, see Holderness (1997, p. 217, 219 and 225), Martin (1997, p. 247), Priestley (1997, pp. 283-284) and Duplessis (1997, pp. 452-461).

20 «Most of the «New Draperies» products were hybrid worsted-woolen «stuffs» or serges, much like those produced in Hondschoote, probably the key progenitor of the English New Draperies» (Munro 2009, pp. 16-17; 2005, pp. 431-484).
} 
It is true that the Castilian market has specific characteristics due to its sparse population with low purchasing power and its poor and very scattered demand. The exception, of course, was the capital ${ }^{21}$. In fact, according to the literature Spain had been dominated by the growth of Madrid and its disproportionately important position in domestic and foreign consumption. "Only the city of Madrid constituted a significant concentrated market in the interior» (Ringrose 1970, pp. 48-57). Indeed, the city of Madrid received approximately one-quarter of the total imported fabrics, a higher percentage than its demographic proportion, which is indicative of the purchasing power of its people (above average) considering the significant portion of the nobility - along with their income, expenses and servants and the royal bureaucracy ${ }^{22}$. The greater purchasing power of Madrid with regard to neighbouring cities is also apparent in the percentage of the more expensive fabrics ${ }^{23}$, the cloths, substantially higher than the rest, $2.53 \%$ vs. $0.16 \%$, about sixteen times greater, as well as the higher weight of baize. However, the value per weight of foreign cloth of English origin continued to be very low, probably for the political reasons already stated. The exception seems to be calamancos, cheaper fabrics than sempiternals, which were consumed more in Madrid - 12 per cent - than in the rest of the cities 8 per cent - that could be explained by the higher proportion of servants (Ringrose 1983, p. 70; Risco 2001, p. 31; see also Sarasúa 1984; Nieto 2006; López García 2008; Dyer 1989). According to Ringrose the most numerous group of workers were servants and, at mid-century, domestic servants made up 11.5 per cent of the entire population. However, according to Risco, servants represented 20 per cent in 1757. In any case, nobles bought clothes for themselves and their families including liveries for servants and supporters, bedding, curtains and other accessories, linens, tablecloths and towels (Table 4).

The relative weights, however, of different fabrics sent to Madrid were not significantly different from those of other cities. Ninety-three per cent corresponded to three types of fabric with a clear predominance of baize (53 per cent) and sempiternals $(28 \text { per cent })^{24}$. Madrid was an important centre of textile goods consumption, but its importance should not overshadow that of the many less wealthy and less populated commercial centres.

21 Ringrose (1973, p. 765) see Tables 1 and 3 regarding population estimations; De Vries (1984, p. 150, 256), Bel (2012), Ringrose (1970, pp. 27-28), Andrés (2011).

22 Some Madrid merchants were major traders. The most significant case was that of José Aguado Correa, lender of the crown and promoter of a royal manufacturing in Valdemoro but he was not the only case. Bartholome Flon was also a creditor of the crown. There were market merchants like Andrew Bringas de la Torre and merchants belonging to the Five Major Guilds. I owe this information to José Nieto.

23 Pinol (2003, p. 635). About luxury, see Berry (1994), Cox (2002-2008; 2003, pp. 26-49).

24 The other sign of higher purchasing power is the higher weight of the baize in Madrid, 53 per cent vs. 43 per cent in the rest of the commercial centres. Fabrics like the sempiternals accounted for 28 per cent in Madrid, compared with 43 per cent in the rest of the cities. 
TABLE 4

TYPES OF TEXTILES IMPORTED TO MADRID AND THE REST OF THE NORTHERN SPANISH SUB-PLATEAU

\begin{tabular}{|l|c|r|r|r|c|c|}
\hline Type of textile & $\begin{array}{c}\text { Total mrs. } \\
\text { SM }\end{array}$ & $\begin{array}{c}\text { \% mrs. } \\
\text { SM }\end{array}$ & $\begin{array}{c}\text { Madrid } \\
(\mathbf{m r s . ~ S M})\end{array}$ & $\begin{array}{c}\text { The rest } \\
(\mathbf{m r s . ~ S M})\end{array}$ & $\begin{array}{c}\text { Madrid } \\
(\%)\end{array}$ & $\begin{array}{c}\text { The } \\
\text { rest (\%) }\end{array}$ \\
\hline Bay & $1,128,428.30$ & 45.62 & $325,219.40$ & $803,208.90$ & 52.71 & 43.27 \\
Sempiternal & 978,209 & 39.55 & $174,610.50$ & $803,598.50$ & 28.3 & 43.29 \\
Callimanco & $217,954.80$ & 8.81 & $72,749.80$ & $145,205.00$ & 11.79 & 7.82 \\
Scarlet cloth & 44,530 & 1.80 & $4,566.00$ & $39,964.00$ & 0.74 & 2.15 \\
Woollen stuff & 44,317 & 1.79 & $5,175.00$ & $39,142.00$ & 0.84 & 2.11 \\
Woollen cloth & $18,668.80$ & 0.75 & $15,629.80$ & $3,039.00$ & 2.53 & 0.16 \\
Cloth & $11,661.20$ & 0.47 & $2,334.20$ & $9,327.00$ & 0.38 & 0.5 \\
Etamine & $7,119.45$ & 0.29 & $1,575.70$ & $5,543.75$ & 0.25 & 0.3 \\
Serge & $5,318.40$ & 0.22 & $4,593.20$ & 725.20 & 0.74 & 0.04 \\
\hline
\end{tabular}

Source: A.G.S., Tribunal Superior de Cuentas, files 854 and 855.

In absolute terms, the rest of the northern Spanish sub-plateau and surrounding areas were also poles of attraction for fabric suppliers and were, in relative terms, more important in the market for imported fabrics. A vast overland network of cities served as small nodes of distributive market for foreign fabric commerce. The rapid growth of these urban centres had probably refocused regional and national trading and consumption links. A significant number of landowners - nobles or otherwise — as well as provincial officials lived in the capital of provinces. Promotion opportunities were possible in these cities even though they were small. Established families had access to municipal functions and newcomers could be sure of lower-level posts and even have access to titles of nobility (Pinol 2003, p. 729). Therefore, it should not seem strange that the capitals consumed more imported fabrics than rural areas. The capitals absorbed two-thirds of imported fabrics and the rest were imported by other provincial centres of a certain size. If we exclude Madrid and its province, there is a change in the percentage, although not in its direction: 58 per cent in the capitals and 42 per cent in the other provincial centres.

The geographic concentration of the market demand for Spanish textiles is moderate. In order to corroborate this statement, we will use the Hirschman - Herfindhal Index. This index is used to measure the oligopolistic concentration of a specific market; that is, the extent to which supply is concentrated in only a few producers. A value for the index equal to one would signify that the market is totally monopolized. In this case, we apply it to demand rather than to the concentration of supply. The same thing would happen: an index with a value equal to one would signify that only one 
province demands the textiles in question. The index is defined as the sum of participations relative to the provinces in the total demand and the formula is

$$
H=\Sigma s i^{2}
$$

where $s i$ is the percentage corresponding to demand in each of the provinces.

However, here we will use the standardized Hirschman-Herfiundhal Index; that is, that the values will be between 0 (where each province demands the same quantity) and 1 (in which only one province demands textiles). The reconciled index is

$$
H^{*}=(H-1 / \mathrm{N}) /(1-1 / \mathrm{N})
$$

where $N$ is the number of provinces.

After calculating, we obtain a value of $H^{*}=0.198$; that is, if we apply the same rule that is used in oligopoly theory, we would obtain an indication of a concentration of low to moderate demand, since values in the range of $0.15-0.25$ are classified as a market and below 0.15 would be an indication that there is no concentration.

Therefore, there was a significant level of «rural» consumption of imported fabrics. In addition, some fabrics were traded by commercial carriers, for which there is no final destination recorded, but it is conceivable that they were distributed in rural areas.

\section{COMMERCIAL MODES}

According to Ringrose, the organization of transport in Castile reached its limits of development at the end of the $18^{\text {th }}$ century, due to its inability to respond to changes produced in the market and the lack of investment in infrastructures ${ }^{25}$. It is clear that the low market integration was constrained by transport problems, but this does not imply that there was not a certain degree of coordinated efforts and networks set up to try to overcome these obstacles.

In general, with respect to the setting up and maintenance of transportation and commercialization networks, not only is there a great emphasis on kinship, but also on language and the regional origins of producers and distributors $^{26}$. These socio-cultural ties compensated for the inexistence of institutions designed to protect such activities and allowed them to expand into ever greater geographical areas and explore new markets. The origin of this network has been linked to street vendors. This work is, in principle,

25 Ringrose (1983, p. 51). See also Madrazo (1984), Uriol (1992, 1980, pp. 707-714), Ringrose (1970, pp. 51-53). For a more recent approach, see Bel (2012) and Grafe (2012).

26 A synthesis in Rúa Fernández (2006, p. 20). "Aquests elements comuns d'identificació (llengua, religió, paisanatge...) els serveixen per donar-se suport mutu en situacions de risc, imprevisió o altres dificultats derivades de la manca de bones infraestructuras». 
performed by individuals who have other occupations for most of the year small farmers, modest artisans, etc - who also, at certain times, engage in the sale of transport services or in distributing their own agricultural products and handcrafts, thus connecting areas with a surplus of goods to those with a deficit in order to avoid empty returns. The use of part-time farmer-carriers tended, however, to reduce the cost of transport but not that of storage of merchandise, which is not usually taken into account. While some of these individuals would specialise in transportation throughout the year, others would set up small businesses, and some would continue combining their primary work with the sale of transport and goods. In many cases the producers, transporters and sellers would have a common geographical origin (district, province), according to the literature ${ }^{27}$. Let us look at the data.

The source reveals a variety of different ways of carrying out the distribution and marketing of foreign textiles. In some cases, the documents state that the goods would pass into the hands of a person other than the merchant who had ordered the product, and who was located in a different neighborhood. A city merchant would acquire fabric, move it to a different neighboring location and transfer it to another individual, who sometimes figured as a «resident» of the place, at other times was simply listed as a «head of household» and was sometimes even listed as a «nobleman». In some cases, the recipient of the goods may have been an employee of the merchant, at other times a merchant of lower category or a correspondent. It is not possible to distinguish between any of these different cases, but we can clearly infer two distinct systems of distribution and trading of imported fabrics.

Group A: In the most frequently used system, a correspondent or a broker - who was usually a resident of Bilbao or Vitoria - remitted fabrics to a merchant of a suburban or rural centre using carriers in 87 per cent of the cases, mostly individual carriers with a servant or family members. In some cases, if their economic situation made it possible, carriers would form a company.

Group B: This system did not include a carrier as a transporter and the exact destination of the fabrics is not known. Only the name of the dealer, trader-carrier, or transporter listed as owner of the goods (on behalf of) and his residence are available. They were mostly small-town residents, carriers who were dedicated to marketing certain products in rural areas, acting as mobile merchants occasionally or permanently or just carriers who operated as retailers and acted as hawkers or peddlers ${ }^{28}$. Transport or merchant activity

27 Muset i Pons (1995, pp. 193-208; 1997, pp. 49-65), Salas (1983, pp. 65-81), and also articles included in Pérez Picazo (1996) and in Torras and Yun (1999), specially see Fontaine (1999, p. 313). For Galician peddlers, see Carmona Badía (1990, p. 74, 75, 94).

28 Castilian Spanish distinguishes between peddler, carrier and muleteer. Authorities Dictionary (1737). 
provided employment throughout the year in some cases and for most of the year in others ${ }^{29}$. This second group can be subdivided into another minority group composed of persons whose name was preceded by the title «Don» ${ }^{30}$. It mainly referred to merchants who, for unknown reasons, had moved to Bilbao to obtain fabrics directly. However, the great majority was, as mentioned, carriers who operated as retailers and acted as hawkers or peddlers. Moreover, it seems that, according to the source, some residents of certain small villages were specialized in or engaged as carriers or in retailing. This is the case of two small villages where the majority of their inhabitants were carriers. One of them, Pesquera (Burgos) is a good example: Twenty-nine of its fifty residents were carriers for an average of almost 9 months a year ${ }^{31}$. The other is Cortiguera, also located in the Sedano Valley (Burgos), with twenty-one residents and six working as carriers 8 months a year ${ }^{32}$. Transport or merchant activity employed some of them throughout the year and others for most of the year. Usually they had small plots of land and some cattle, apart from the animals used to carry merchandise. By taking note of the surnames, we can conclude that some were related to each other, which is not surprising given the size of the village. Both sites had poor, mountain farming, which could explain this specialization.

Thanks to the general and specific responses from the Catastro of the Marquis of Ensenada from around 1752, some features of the muleteers, who appeared to deserve the confidence that traders deposited in them, can be ascertained.

A total of 116 towns are referred to as places of residence of muleteers; of these, sixteen are unidentified. Of the 100 remaining towns, forty-five were in Burgos, nineteen in Álava, eight in Vizcaya, five in Madrid, five in Segovia and five in Santander. The others were distributed between Guipúzcoa (two), Guadalajara (two), Salamanca (two), Burgos/Soria (three), Toledo (two), Zamora (one) and Navarra (one).

Bilbao, the landing place of goods and point of departure for distribution in the interior, only appears occasionally as the place of residence of muleteers. The Vizcayan towns, Bilbao among them, as well as Encartaciones, did not follow the autonomous (foral) hereditary regime, but rather the Castilian one, which was more egalitarian. In the foral system, one of the children, in general the eldest, received the inheritance, while disinheriting the rest with a silver coin, a shingle and the most unproductive tree. It was a system

29 They usually had small plots of land and some cattle, apart from the animals used to carry merchandise.

30 «Don» cannot be put on a level of Mister or Lord, but is a title denoting nobility. According to Braudel «... one cannot properly term «bourgeois» the host of civil servants such as the letrados in the king's service, habitually prefixing their names with a Don, lesser nobles or aspirant nobles far more than true bourgeois» (Braudel 1995, p. 727).

31 Catastro de Ensenada, Respuestas generales de los respectivos pueblos.

32 Catastro de Ensenada, Respuestas generales de los respectivos pueblos. 
similar to the Catalan hereu. Those who lived under the Castilian hereditary regime had the right to a share of the inheritance. Only thanks to the «tercio de mejora y al de libre disposición" could parents increase the proportion of one of the descendants, but not completely disinherit the rest of their children. It is significant that the Vizcayan carriers mostly belonged to zones employing the Castilian inheritance system, such as Bilbao and Gordejuela, Güeñes, Sodupe, Sopuerta, Zalla in the Encartaciones. It should be noted that Encartaciones was a Spanish-speaking region. Another Basque province with quite a few carriers was Alava, where the egalitarian Castilian hereditary system also operated and was mostly Spanish speaking. It does not seem that speaking a language other than Spanish was an essential element for establishing ties and building confidence. On the other hand, the fact that the second-born children were not disinherited made them susceptible, in the case of belonging to a family of small landowners, to take responsibility for default or fraud. If they were to escape with the goods they were carrying, they would lose their rustic property, which might be of only slightly more value than those goods.

The majority of the locations (45 per cent) designated as the place of residence of carriers were in Burgos, usually in villages located in the foothills of the Cantabrian mountains, as well as several in Santander (Valderredible, Reinosa, Villaescusa de Ebro). The agricultural poverty of the mountains encouraged locals to emigrate or to look for jobs in secondary and tertiary sectors. The Catastro in some of these places provides information that sheds light on these carriers. The responses of four - Turzo, Sedano, Pesquera and Castil de Peones, among others, are particularly enlightening ${ }^{33}$. Turzo stood at $850 \mathrm{~m}$ above sea level, Sedano at $752 \mathrm{~m}$, Pesquera at $642 \mathrm{~m}$ and Castil de Peones at $793 \mathrm{~m}$, all four in high mountainous areas. The Catastro established the wages paid for each activity (transport, agriculture...) and sometimes also the days ${ }^{34}$ or months that were dedicated to each of them. A farmer was estimated to have put in 120 days of work per year, with incomes estimated at $3 \mathrm{rs} . /$ day (360 rs./year).

Data taken from the Catastro suggest that some farmers in certain months worked in transportation with their mule trains (mixed muleteers), others were fundamentally muleteers and marginally farmers, in other cases the husbands were muleteers and the family cultivated the land (full-time muleteers). In any case, the family of the muleteer or the muleteer himself usually had links to the agricultural activity of the village. In addition to those who hired them, they were acquaintances of the customs and tax agents, who noted their name and neighborhood and the origin and destination of the goods.

33 Catastro de Ensenada, Respuestas Generales, Turzo (Burgos), 29 septiembre 1752; Sedano (Burgos), 25 marzo 1753; Pesquera, valle de Sedano (Burgos), 16 octubre 1752; Castil de Peones (Burgos), fs. 120 y ss.

34 Regarding the number of days dedicated to work, see García-Zuñiga (2013). 
It is more difficult to distinguish between those who did «a porte», that is, selling a service in exchange for an agreed compensation, and those who, in addition to this activity, whether regular or occasional, carried out their own trade with part of the products that they transported. These were not necessarily mutually exclusive activities, although they required having their own capital and a likely clientele.

In Turzo (Burgos), there were twenty carriers of a total of thirty-one household heads. Nine were explicitly qualified full-time muleteers. These received an average of 278 reales in wages a year and the remainder received 92 reales. The surveyors objected that the declared profits (92 reales) were short «due to the maintenance of the family», to which the carriers responded "that the main thing that supports them is the cultivation of land carried out by their women and families». The revenues obtained from transport were completed with what the family obtained cultivating either their own or leased land. The village of Sedano (Burgos) had fifty-three household heads; of its nine carriers, four were full-time carriers and five were also listed as part-time carriers/farmers. As part-time carriers, they earned 115 reales on average, and as full-time carriers, 175 reales. Income from agriculture was 168 reales on average. A part-time carrier would earn up to 282 rs./year: 168 reales from the agricultural activities and 115 reales as a part-time carrier. Theoretically, it was estimated that a full-time farmer devoted 120 days to agricultural activities; our mixed carriers, on average, only spent 56 days working the land. The time devoted to transport, however, is not clear.

Pesquera, in the province of Burgos, had about fifty household heads (forty-three in addition to fourteen widows). Of them, thirty were dedicated in one way or another to muleteering. Seven of the full-time muleteers earned on average 192 reales. Part-time muleteers (twenty-three) obtained income as farmers, and on average 109 reales from agricultural activities, but 421 reales as muleteers that is a total amount of 530 rs./year. Part-time carriers had an income superior to those who only engaged in transport. The carrier-laborers devoted some seven and a half months a year (86 per cent) to transport and little more than 1 month (14 per cent) to agriculture.

Castil de Peones, La Bureba, had a population of sixty household heads including twelve widows and two inhabitants. Of its twenty-three carriers, only two appear not to have worked as farmers. The rest worked an average of almost 6 months as muleteers and spent an average of 2 months per year as laborers.

A final example of these carriers and part-time farmers: in Castil de Lences, La Bureba, Francisco Díaz Guilarte worked as a muleteer with seven caballerías mayores, from Bilbao to Madrid and elsewhere and with these beasts of burden he «cultivated some land» ${ }^{35}$.

We have observed farmers who dedicated part of their activity to muleteering. However, as has been seen, a full-time farmer is attributed 120 days

\footnotetext{
${ }^{35}$ Castil de Lences (Burgos), rsep. 32, f. 142.
} 
of work per year, at $3 \mathrm{rs} . /$ day, $360 \mathrm{rs}$./year. Theoretically, a laborer only needed to spend 4 months a year to earn a living from this activity. In principle, it is estimated that it was in the months without agricultural activity, the empty months, when they were engaged in other activities. But with respect to our carrier/laborers, the number of days that they actually worked in agriculture was far fewer than 120 days. It appears that those who engaged in transportation did so because the land they cultivated, whether owned or leased, did not provide enough for them to make a living all year round. They did not decide to dedicate their leisure time to increasing their income. They were not, therefore, peasants who spent the empty months between farming, drifting. Either they were small farmers who, in order to live, had to supplement their income working as muleteers or were carriers who were engaged (or their family members) in agricultural tasks at certain very specific times of the year. It was also sometimes the case that they were poor peasants without land. In any case, most of them had roots in the land, no doubt with home ownership and perhaps some rented or owned land.

Based on the dates that they went through customs, we know that, although there were annual cycles, the traffic was not interrupted in any month of the year. This was either because there were carriers who worked full-time, or because agricultural activities did not coincide according to geographical areas; there was always carriers plying their trade between Bilbao and the interior.

Trust in these carriers could not have been based on proximity, or on a language other than Castilian, or on family ties. If they were entrusted with the transport of valuable goods (fabrics), it was because of their professionalism and the fact that their previous activity inspired the confidence that they would honor the contract. In case of failure to do so, however, they were well known, with a fixed home, and not only with one or more mule trains, but with goods and family in a known place. In the case of fraud the injured party, although at the expense of a trial, could at least be compensated in part.

As the source did not provide information about the final destination of fabrics of this second group, we have analyzed the first one (Group A), which in any case is the system most used in commercial distribution, in greater depth. Two facts can be deduced from the information: the existence of a division between capital cities and provinces, and the commercial modes or networks.

First, through the geographic distribution of imported fabrics according to the data plotted in Map 2 - we are able to establish a division between capital cities (in red) and the rest of the provinces (in off-white). The capital cities had absorbed two-thirds of imported fabrics, and the rest were imported by other provincial centers of a certain size. A significant proportion of landowners (nobles or otherwise), as well as provincial officials, lived in the provincial capitals. It should not seem strange, therefore, that the capitals consumed more imported fabrics than rural areas (Map 3). 


\section{MAP 2}

DISTRIBUTION ACCORDING TO THE DEMAND OF CAPITALS OF PROVINCES AND RURAL AREAS OF THESE PROVINCES

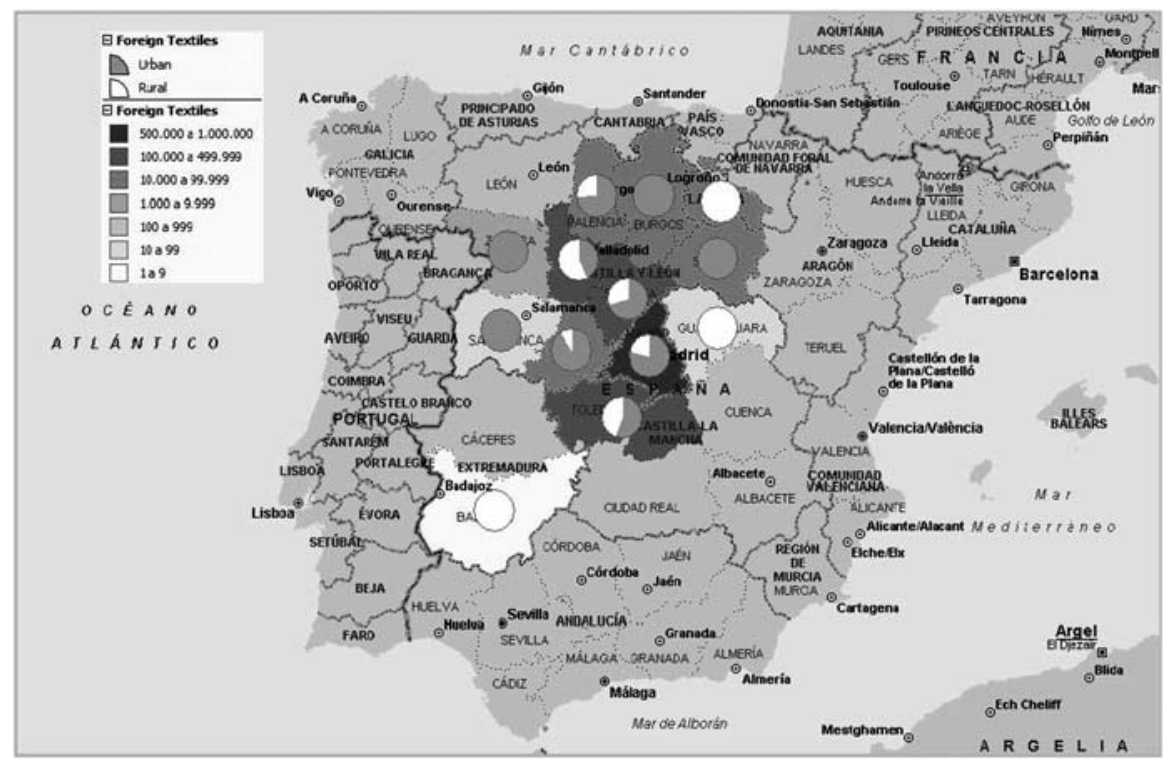

In any case, the division between the capital cities and elsewhere in the province must be interpreted with caution, as there is no absolute certainty that the fabrics that were destined for the capital city of a province were sold and consumed in it. They could have been forwarded to rural markets and fairs, or wealthy peasants could have visited the capital to stock up on certain manufactured goods. There was also a significant level of «rural» consumption of imported fabrics. In addition, some fabrics were traded by group B, the group of commercial carriers, peddlers or hawkers for whom there is no final destination recorded, but it is conceivable that they were distributed in rural areas. Some significant rural centers that received fabrics were clearly linked to the existence of fairs (Martin Muñoz de Posadas or San Esteban de Gormaz).

Second, it could be inferred that, the broker, the carrier and the merchant were residents of the same, or nearby, provinces ${ }^{36}$. Distance would have been an obstacle to providing reliable information and directly proportional to the distance between the shipper and the receiver, about $400 \mathrm{~km}$ inland. Merchants needed to trust their trading partners.

36 On transport in Spain in the $18^{\text {th }}$ century, see Ringrose (1972, Ch. IV), Madrazo $(1984,2001)$; López García and Madrazo (1996), Bel (2012). 
MAP 3

RESIDENCE OF THE CARRIERS

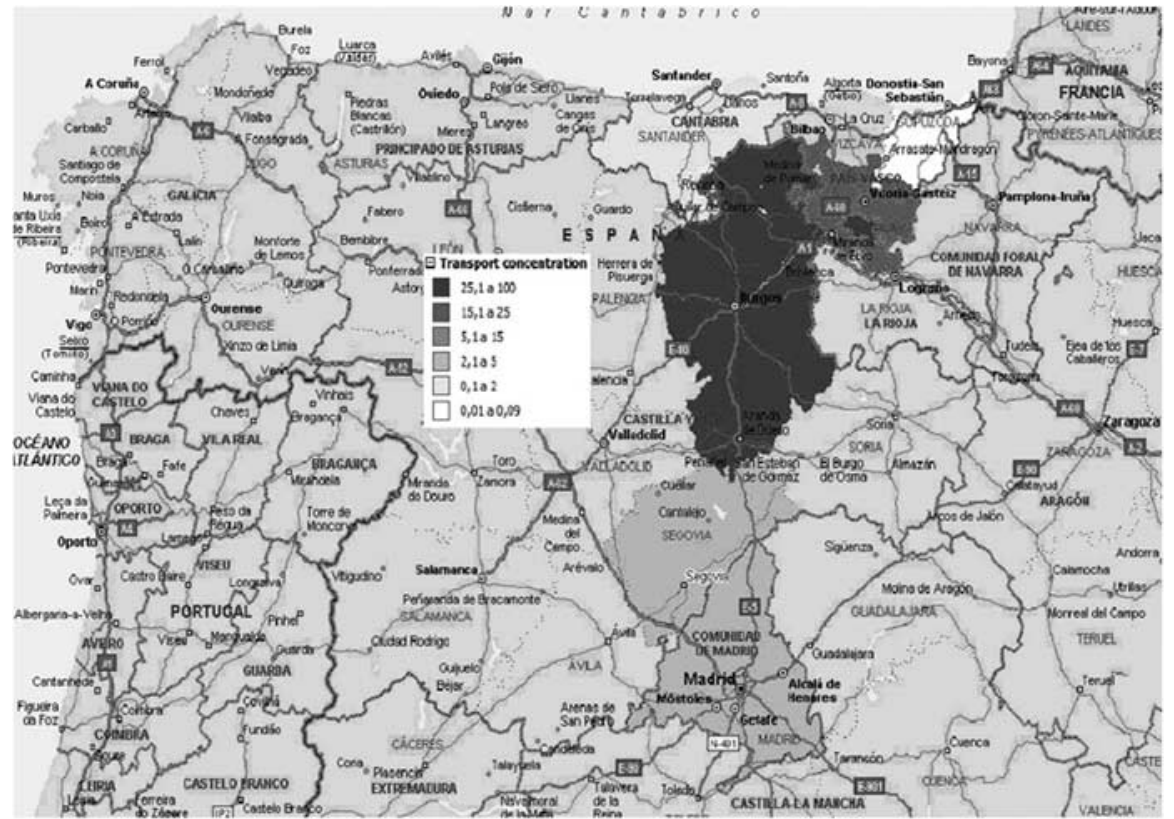

After carrying out a survey of the place of residence of each person involved in the distribution of fabrics, we can say that there seems to have been clear specialization and a close network based on trust. The percentages indicate that none of the carriers were from the point of departure, Bilbao. No carrier was a resident of that county (Vizcaya). There were a relatively high percentage of residents of Álava, the province of one of the inland customs. Most of the carriers, however, came from Burgos, especially from a particular area of Burgos ${ }^{37}$. In fact, it is surprising that merchants from Madrid retained only a few carriers from the province of Madrid (Utanda 2001, pp. 341-343) (Table 5).

Although there are some cases in which the trader, receiver and carrier were residents of the same province, in most cases there is no such link.

Thus, neighborhood, proximity or family ties were not the reasons the merchants or correspondents chose the carrier. In this sense, the Castilian

37 Bedón, Cantabrana, Castil de Peones, Dobro, Escobados, Las Quintanillas, Medina de Pomar, Mena, Pesadas, Quintanavides, Termiñón, Torme, Torres, Valdivielso, Villaescusa, Villanueva la Blanca. 
TABLE 5

RESIDENCE OF THE CARRIER AND PROVINCES OF TRANSPORTED FABRICS IN MRS., 1710-1714 (PERCENTAGE)

\begin{tabular}{|l|c|c|c|c|}
\hline & \multicolumn{3}{|c|}{ Fabric destination } & \\
\hline Carrier's residence & Madrid & Segovia & Toledo & Total (\%) \\
\hline Unknown & 6.57 & 2.24 & 31.61 & 7.84 \\
Álava & 16.45 & 42.96 & 26.85 & 19.65 \\
Burgos & 69.25 & 15.83 & 41.54 & 62.34 \\
Guipúzcoa & 0.11 & & & 0.08 \\
Madrid & 1.51 & 32.82 & & 4.37 \\
Santander & 0.79 & & & 0.67 \\
Segovia & 5.33 & 6.15 & & 5.05 \\
\hline Total & 100 & 100 & 100 & 100 \\
\hline
\end{tabular}

Note: Carriers included in «Unknown» were probably from Burgos province.

distribution network structure was, in the $18^{\text {th }}$ century, a solid and healthy network based on contracts. ${ }^{38}$

Acting as a market tranquilizer, trust was essential in any kind of transaction, a kind of social capital that reduced transaction costs and impact on institutions (Beckert 2005, p. 6; Coleman 1990; Putnam 1993; Fukuyama 1995). Surely there had to be a certain level of trust between shipper, receiver and carrier, but it was not derived from family, friendship or regional ties (Greif 2004; see also Toch 1993; Chartres 1995; Pettit 1995; Nee 2003; Guiso et al. 2004; Botticini and Eckstein 2007; Bénabou and Tirole 2010; Tabellini 2010). Brokers, carriers and merchants had the connections required to conduct trade based on their personal reputation and individual liability. Instead of appearing as an unwieldy structure, this network is based on responsibility and reputation with the control of the Consulado that would manifest a high degree of modernity.

\section{CONCLUSIONS}

As was pointed out by W.B. Stephens, among others, our results lead us to focus upon the significance of fiscal sources as being the most reliable and

38 Ordenanzas (1737) cap. XII, no. 2, 3 and 4, p. 83. Si fueren los géneros, o mercaderías que así se compraren para conducirse por tierra, será de la obligación del Comisionado alquilar las carga que huviere de enviar, con intervención de uno de los Corredores de Arrieros, que para este efecto están nombrados por esta Noble Villa; atendiendo por este medio, a que en caso de cometer el Arriero conductor algún fraude, quede asegura la hacienda que se enviare, respecto de las fianzas que tienen dadas los tales Corredores para en estos casos. 
accessible for an in-depth study of consumption and distribution (Stephens 1969, pp. 228-248). Using information from fiscal documents, this paper has contributed the first qualitative and quantitative analysis of distribution networks in the Spanish northern sub-plateau in modern times and, therefore, allows us to better understand how commercial and trading networks operated. Our findings, in this sense, fill a significant gap in knowledge as to the distribution system in Castile and re-examines the demand for British fabrics and its implications for peninsular textile producers.

Among $18^{\text {th }}$-century writers, there was a widespread notion that Spain produced woollen fabrics using Castilian wool. Today it is estimated that Spanish weavers were not competitive in the production of high-quality fabrics; instead, they were competitive in medium quality, in 26 no ranges and especially in the lower quality range (García Sanz 1994, pp. 409, 410, 425, 426-427). Our source, however, shows that foreign competition was not limited to fine or superfine cloth. Throughout the $17^{\text {th }}$ century, there were a number of changes in the rural wool textile industry concerning the kind of cloth produced. It is true that northern Europe (France, Holland and England) still demanded Spanish wool for their expanding textile industries, but the type of fabric that England was producing changed to the new draperies during the $17^{\text {th }}$ century. The data indicate that most of the imported fabrics came from the so-called new English drapery and the wool used was non-merino wool. Although fabric types were quite diverse, three in particular had a practical monopoly on imports: sempiternal, baize and calamanco. The primary imports were fabrics of mid-quality and even low quality. In addition, foreign competition was not limited to fine or superfine cloth, as has been mentioned previously.

It is true that fabrics imported to Spain from, at that moment, enemy countries, England and Holland, through the port of Bilbao, were not the only foreign textiles consumed in Spain under Bourbon rule. This could limit the scope of some of our conclusions, but does not invalidate them. It must be remembered that the state of war was more common than peace at that time (Tainter 2000; Tilly 1975). In fact, the quantity imported per year was quite high during times of war.

The final two sections of this paper focus upon the final geographic destination of the majority of imported textiles, which allows us to obtain, for the first time, a visual and clearly defined representation of the demand for foreign cloth in Spain. Madrid consumed a large proportion of these imported fabrics, but most were distributed by cities in the Duero Valley, the head of the Ebro and surrounding areas. Madrid was an important centre of consumption, but other towns also absorbed large quantities of manufactured goods, including imported and domestic textiles. Most of the fabric considered was consumed in provincial capitals, but some consumption can be considered rural. It is necessary to change the focus of regional and national trading links to the rapidly growing urban centres. The study suggests the existence of an integrative mercantile structure akin to that for fabrics. 
With respect to the import product distribution network consisting of different bilateral relationships between the carrier and the consumer or purchaser (Mauleon et al. 2005, p. 4), it must be pointed out that the nature of these networks was not traditional, based on kinship, family or place of birth, but rather a modern one, based exclusively on economic links, vested interests, Consulado regulations and trust.

Hence, what is therefore confirmed is that the distribution of non-perishable goods such as drapery, or fabrics in general, was not only influenced by seasonal considerations. It is true that seasonal factors, climate and the agricultural cycle had specific effects on transport, especially on those distributors who were farmers and were constrained by their agricultural activity. In fact, these individuals became part-time carriers. Our data, however, confirm that a large percentage of individuals apparently had a high degree of specialisation and worked as carriers during the whole year (Madrazo 1981, pp. 39-71).

The tentative conclusions here advanced have the intention of elaborating on and providing some new perspectives on fabric consumption and their commercial and transportation modes in Castile. It remains an area in which further research is needed before any formal modeling. We hope the present paper has suggested new perspectives and will contribute to stimulating further studies.

\section{PRIMARY SOURCES}

Archivo General de Simancas, Simancas, España, Tribunal Superior de Cuentas.

\section{REFERENCES}

Adler, (2011): «Market, Hierarchy, and Trust: The Knowledge Economy and the Future of Capitalism». Organization Science 12 (2), pp. 215-234.

ANDRÉs, J. I. (2011): «Fiscalidad y precios en Castilla en el Siglo XVII: los precios del vino en Madrid, 1606-1700». Revista de Historia Económica, $2^{\text {nd }}$ Series 29 (2), pp. 269-298.

Alexander, N., and Akehurst, G. (1998): «Introduction: The Emergence of Modern Retailing, 1750-1950». Business History 40 (4), pp. 1-15.

Axelrod, R. (1984): The Evolution of Cooperation. New York: Basic Books.

BAKer, T., and Gerhold, D. (1993): The Rise and Rise of Road Transport, 1700-1990. Cambridge: Cambridge University Press.

Barro, R. J., and McClearly, R. M. (2006): "Religion and Economy». Journal of Economic Perspectives 20 (2), pp. 49-72.

BeCKert, J. (2005): Trust and the Performative Construction of Markets, MPIfG Discussion Paper 05/8. Cologne: Max Planck Institute for the Study of Societies.

Ben-Porath, Y. (1980): «The F-connection: Families, Friends, and Firms and the Organization of Exchange». Population and Development Review 6 (1), pp. 1-30.

BeL, G. (2012): Infrastructure and the Political Economy of Nation Building in Spain, 1720-2010. Londres: Sussex Academic Press. 
Bénabou, R., and Tirole, J. (2010): «Individual and Corporate Social Responsibility». Economica 77 (305), pp. 1-19.

Berry, C. H. (1994): The Idea of luxury: A Conceptual and Historical Investigation. Cambridge: Cambridge University Press.

Bilbao L. et Fernández de Pinedo, E. (1994): «Wool exports, transhumance and land use in Castile in the sixteenth, seventeenth and eighteenth centuries», in Thompson I. A. A. et Yun Casalilla B. (eds), The Castilian Crisis of the Seventeenth Century. New Perspectives on the economic and social History of seventeenth century Spain. Cambridge: CUP, pp. 101-114.

Bonney, R. (ed.) (1999): The Rise of the Fiscal State in Europe, c.1200-1815. Oxford and New York: Oxford University Press.

Botticini, M., and Eckstein, Z. (2007): «From Farmers to Merchants, Conversions and Diaspora: Human Capital and Jewish History». Journal of the European Economic Association 5 (5), pp. 885-926.

Braudel, F. (1995): The Mediterranean and the Mediterranean World in the Age of Philip II, vol. II. Berkeley: University of California.

BRowden, P. (1962): The Wool Trade in Tudor and Stuart England. London: MacMillan and Co.

Burley, K. H. (1958): «An Essex Clothier of the Eighteenth Century». The Economic History Review 11, pp. 289-301.

Canga Argüelles, J. (1968): Diccionario de Hacienda con aplicación a España (1834), vol. II. Madrid: Instituto de Estudios Fiscales.

Carmona, X. (1990): El atraso industrial de Galicia. Auge y liquidación de las manufacturas textiles (1750-1900). Barcelona: Ariel.

Coleman, D. C. (1969): "An Innovation and its Diffusion: The «New Draperies»». Economic History Review, $2^{\text {nd }}$ Series 22, pp. 417-429.

Coleman, J. (1990): Foundations of Social Theory. Cambridge, MA and London: The Belknap Press of Harvard University Press.

Cox, J. C. (2004): "How to Identify Trust and Reciprocity». Games and Economic Behavior 46 (2), pp. 260-281.

Cox, N. (2000-2008): The Complete Tradesman: A Study on Retailing, 1550-1820. Aldershot: Ashgate.

Cox, N., and Dannehl, K. (2007): Dictionary of Traded Goods and Commodities 1550-1820. Available at http://www.british-history.ac.uk/source.aspx?pubid=739.

Chartres, J. A. (1995): «Market Integration and Agricultural Output in Seventeenth-, Eighteenth-, and early Nineteenth-Century England». Agricultural History Review 43 (2), pp. 117-138.

CHILd, SiR Josiah (1693): An Essay on Wool and Woollen Manufacture for the Improvement of Trade to the Benefit of Landlords, Feeders of Sheeps, Clothiers and Merchants. London: Printed for Henry Bonwicke.

Childs, W. R. (1978): Anglo-Castilian Trade in the Later Middle Ages. Manchester: Manchester University Press.

CHILDS, W. R. (2003): "Commercial Relations between the Basque Provinces and England in the Later Middle Ages, c.1200-1500». Itsas Memoria. Revista de Estudios Marítimos del País Vasco 4, pp. 55-64.

Dasgupta, P. (2000): "Trust as a Commodity», in Diego Gambetta (ed.), Trust: Making and Breaking Cooperative Relations. New York: Blackwell, pp. 49-72.

Dasgupta, P. (2009): «Trust and Cooperation among Economic Agents». Philosophical Transactions of the Royal Society B 364 (1533), pp. 3301-3309.

Davis, R. (1954): «English Foreign Trade 1660-1700». Economic History Review, $2^{\text {nd }}$ Series 7 (2), pp. 150-166. 
Denzel, M. A.; De Vries, J., and Rössner, P. R. (eds) (2011): Small is Beautiful? Interlopers and Smaller Trading Nations in the Pre-industrial Period: Proceedings of the XVth World Economic History Congress in Utrecht (Netherlands). Stuttgart: Franz Steiner Verlag.

Dickson, P. G. M. (1967): The Financial Revolution in England: A Study in the Development of Public Credit, 1688-1756. London: Macmillan.

Duplessis, R. (1997): «One Theory, Two Draperies, Three Provinces, and a Multitude of Fabrics: The New Drapery of French Flanders, Hainaut, and the Tournaisis, c.1500-c.1800», in N. Harte (ed.), The New Draperies in the Low Countries and England, 1300-1800. Pasold Studies in Textile History no. 10, Oxford and New York: Oxford University Press, pp. 129-172.

Dyer, C. (1989): "The Consumer and the Market in the Later Middle Ages». The Economic History Review 42 (3), pp. 305-327.

Edwards, J., and Ogilvie, S. (2012): "Contract enforcement, institutions, and social capital: the Maghribi traders reappraised». The Economic History Review 65 (2), pp. 421-444.

FERnÁndEZ-DE-Pinedo, E. (2004): «Production et consommation de draps de laine en Espagne à travers les droits fiscaux de Bolla (Catalogne) et de Sellaje (Bilbao) au XVIIème siècle», in G. L. Fontana and G. Gayot (eds), Wool: Products and Markets (13th-20th Century). Padova: CLEUP, pp. 464-465.

FERnÁNDEZ-DE-Pinedo, N. (2012): «Tax Collection in Spain in the 18th Century: The Case of the «decima»», in J. I. Andrés Ucendo and M. Limberger (eds), Taxation and Debt in the Early Modern City. London: Pickering and Chatto, pp. 101-111.

Fisher, F. J. (1950): «London's Export Trade in the Early Seventeenth Century». The Economic History Review, New Series 3 (2), pp. 151-161.

Fontaine, L. (1999): «Redes de buhoneros (vendedores ambulantes) y desarrollo del consumo en Europa durante los siglos XVII y XVIII», in J. Torras and B. Yun (eds), Consumo, condiciones de vida y comercialización. Cataluña y Castilla, siglos XVII-XIX. Valladolid: Junta de Castilla y León, pp. 312-321.

Funuyama, F. (1995): Trust: The Social Virtues and the Creation of Prosperity. London: Penguin.

Gambetta, D. (ed.) (1988): Trust. Making and Breaking Cooperative Relations. New York: Blackwell.

García SANZ, Á. (1994): «Competitivos en lanas, pero no en paños: lana para la exportación y lana para los telares nacionales en la España del Antiguo Régimen». Revista de Historia Económica 12 (2), pp. 397-434.

García-Zuñiga, M. (2013): "Fêtes chômées et temps de travail en Espagne (1250-1900)», in C. Maitte and D. Terrier (eds), Le temps de travail en longue durée. Rennes: Presses Universitaires de Rennes (forthcoming).

GIRARD, A. (1951): Le commerce français à Seville et Cadix au temps des Habsburg. Paris: E. De Boccard.

Grafe, R. (2012): Distant Tyranny. Markets, Power and Backwardness in Spain 1650-1800. Princeton: Princeton University Press.

Granovetter, M. (1973): «The Strength of Weak Ties». American Journal of Sociology 78 (6), pp. 1360-1380.

GreIF, A. (1993): «Contract Enforceability and Economic Institutions in Early Trade: The Maghribi Traders' Coalition». American Economic Review 83 (3), pp. 525-548.

GreIF, A. (1994): «Cultural beliefs, and the Organization of Society: A Historical and Theoretical Reflection on Collectivist and Individualist Societies». Journal of Political Economy 102, pp. 912-950.

GreIF, A. (2004): «Institutions and Impersonal Exchange: The European Experience». Stanford Law and Economics Olin Working Paper, No. 284. 
GreIF, A. (2006): «Family Structure, Institutions, and Growth: The Origins and Implications of Western Corporation». American Economic Review 96 (2), pp. 308-311.

Guiso, L.; Sapienza, P., and Zingales, L. (2004): «The Role of Social Capital in Financial Development». American Economic Review 94 (3), pp. 527-556.

Guiso, L.; SapienZa, P., and Zingales, L. (2008): «Trusting the Stock Market». Journal of Finance 63 (6), pp. 2557-2600.

Gunn, S.; Grummitr, D., and Cools, H. (2007): War, State and Society in England and the Netherlands, 1477-1559. Oxford: Oxford University Press.

Hamilton, E. J. (1947): War and Prices in Spain, 1651-1800. Cambridge, MA: Harvard University Press.

HaRT, M. T. (1995): «The Emergence and Consolidation of the «Tax State»: II. The Seventeenth Century», in R. Bonney (ed.), Economic Systems and State Finance. Oxford: Clarendon Press, pp. 281-294.

Hart, M. T.; Jonker, J., and Van Zanden, J. L. (1997): A Financial History of the Netherlands. Cambridge: Cambridge University Press.

Holderness, B. A. (1997): «The Reception and the Distribution of the New Draperies in England», in N. B. Harte (ed.), The New Draperies in the Low Countries and England, 1300-1800. Oxford: Oxford University Press, pp. 217-243.

Kamen, H. (1975): La guerra de Sucesión en España, 1700-1715. Barcelona: Ariel.

Kennedy, P. (1989): The Rise and Fall of the Great Powers. New York: Vintage Books.

Kerridge, E. (1985): Textile Manufacturers in Early Modern England. Manchester: Manchester University Press.

LeE, R. (2011): «Commerce and Culture: A Critical Assessment of the Role of Cultural Factors in Commerce and Trade from c.1750 to the Early Twentieth Century», in R. Lee (ed.), Commerce and Cultures. Nineteenth-century Business Elites. Survey: Ashgate, pp. 1-36.

López García, J. M. (2008): «El henchimiento de Madrid. La capital de la monarquía hispánica en los siglos XVII y XVIII». Working Paper. Available at http:/l www.historiasocial.org/wp-content/uploads/2008/05/lopez2.pdf.

López García, J. M., and Madrazo, S. (1996): «A Capital City in the Feudal Order: Madrid from the Sixteenth to the Eighteenth Century», in P. Clark and B. Lepetit (eds), Capital Cities and their Hinterlands in Early Modern Europe. Aldershot: Scholar Press, pp. 119-142.

López Losa, E. (2013): «The Legacy of E. Hamilton. New Data for the Study of Prices in Spain, 1650-1800». Investigaciones de Historia Económica-Economic History Research 9 (2), pp. 75-87.

Madrazo, S. (1981): «Precios del transporte y tráfico de mercancías en la España de finales del Antiguo Régimen». Moneda y Crédito 159, pp. 39-71.

Madrazo, S. (1984): El sistema de transportes en España 1750-1850. 2 Vols. (Vol. I La Red Viaria and Vol. II El Tráfico y los Servicios). Madrid: Tecnos.

Martin, L. (1997): "The Rise of the New Draperies in Norwich, 1550-1622», in H. Harte (ed.), The New Draperies in the Low Countries and England. Oxford and New York: Pasold Studies, Textile History no. 10, pp. 245-274.

Mauleon, A.; Sempere-Monerris, J., and Vannetelbosch, V (2005): «Networks of Manufacturers and Retailers». Discussion Paper UCL 2005-36.

Morineau, M. (1985): Incroyables Gazettes et Fabuleux Métaux. Cambridge and Paris: Cambridge University Press and Maison des Sciences de l'Homme.

Munro, J. (2005): «Spanish Merino Wools and the Nouvelles Draperies: An Industrial Transformation in the Late Medieval Low Countries». Economic History Review LVIII, 3, pp. 431-484. 
Munro, J. (2009): «Three Centuries of Luxury Textile Consumption in the Low Countries and England, 1330-1570: Trends and Comparisons of Real Values of Woollen Broadcloth (Then and Now)», in K. Vestergård Pedersen and M-L. B. Nosch (eds), The Medieval Broadcloth: Changing Trends in Fashions, Manufacturing and Consumption. Ancient Textile Series, vol. 6. Oxford: Oxbow Book, pp. 1-73.

Muset i Pons, A. (1995): «Los arrieros y negociantes de Calaf y Copons y su implantación en el mercado español en el siglo XVIII». Revista de Historia Industrial 8, pp. 193-208.

Muset i Pons, A. (1997): Catalunya i el mercat espanyol al segle XVIII: els traginers i els negociants de Calaf I Copons. Barcelona: Publicacions de I 'Abadía de Montserrat.

NAsh, R. C. (2005): «The Organization of Trade and Finance in the British Atlantic Economy, 1600-1830», in P. A. Coclanis (ed.), The Atlantic Economy during the Seventeenth and Eighteenth Centuries. Columbia: University of South Carolina Press, pp. 95-151.

NeaL, L. (1990): The Rise of Financial Capitalism: International Capital Markets in the Age of Reason. Cambridge: Cambridge University Press.

NeE, V. (2003). "New Institutionalism, Economic and Sociological». CSES Working Paper Series, Paper 4.

Nemnich, P. A. (1799): Universal European Dictionary of Merchandise. London: Printed by J. Johnson in St. Pauls Church Yard.

Nieto, J. A. (2006): Artesanos y mercaderes. Una historia social y económica de Madrid (1450-1850). Madrid: Fundamentos.

ORDENANZAS (1737): de la Ilustre Universidad y Casa de Contratación de la M.N. y M. L. Villa de Bilbao,, reprint 1796, cap. XII, no. 2, 3, and 4.

Parker, G. (1979): Spain and The Netherlands, 1559-1659: Ten Studies. London: Collins.

Pérez Picazo, $\mathrm{M}^{\mathrm{a}}$ T. (ed.) (1996): Els Catalans a Espanya, 1760-1914. Barcelona: Universitat de Barcelona.

Petтiт, Рн. (1995): «The Cunning of Trust». Philosophy \& Public Affairs 24 (3), pp. 202-225.

Pinol, J.-L. (ed.) (2003): Histoire de l'Europe Urbaine, vol I. Paris: Le Seuil.

Prichard Lloyd, M. F. (1950): «The Decline of Norwich». The Economic History Review, $2^{\text {nd }}$ Series 3, pp. 371-377.

Priestley, U. (1997): "Norwich stuffs, 1600-1700», in N. B. Harte (ed.), The New Draperies in the Low Countries and England, 1300-1800. Oxford and New York: Oxford University Press, pp. 275-288.

Putnam, R. (1993): Making Democracy Work: Civic Traditions in Modern Italy. Princeton: Princeton University Press.

Ramos, F. (2010): Pautas de consumo y Mercado en Castilla 1750-1850. Economía familiar en Palencia al final del Antiguo Régimen. Madrid: Silex Universidad.

Risco, A. (2001): «Mantener una casa. Modelos familiares y economía doméstica hacia 1766», in R. Fernández and J. Soubeyrous (eds), Historia social y literatura. Familia y clases populares en España (siglos XVIII y XIX). Lleida: Ed. Milenio, pp. 37-56.

Ringrose, D. R. (1970): Transportation and Economic Stagnation in Spain, 1750-1850. Durham, NC: Duke University-Press.

Ringrose, D. R. (1972): Los transportes y el estancamiento económico de España (1750-1850). Madrid: Edit. Tecnos.

Ringrose, D. R. (1973): "The Impact of a New Capital City: Madrid, Toledo and New Castile, 1560-1660». Journal of Economic History 33, pp. 761-791.

Ringrose, D. R. (1983): Madrid and the Spanish Economy, 1560-1850. Berkeley: University of California Press.

RÚA FernáNDEZ, C. (2006): «Els Catalans i el mercat madrileny al segle XVIII». Boletín del Institut Universitari d'Historia Jaume Vicens Vives 6, pp. 18-21. 
SALAS, N. (1983): «Ramblers, traginers i mulers (siglos XVIII-XIX)». Recerques 13, pp. 65-81. SARASÚa, C. (1984): Criados, nodrizas y amos. El servicio doméstico en la formación del mercado de trabajo madrileño, 1758-1868. Madrid: Siglo XXI.

Schneider, J. (1978): «Peacocks and Penguins: The Political Economy of European Cloth and Colors». American Ethnologist 5 (3), pp. 413-447.

Schumpeter, E. B. (1960): English Overseas Trade Statistics 1697-1808. Oxford: Clarendon Press.

SmaIL, J. (1999): Merchants, Markets and Manufacture: the English Wool Textile Industry in the Eighteenth Century. London: Palgrave-MAcMillan.

StePhens, W. B. (1969): "The Cloth Exports of the Provincial Ports, 1600-1640». The Economic History Review, New Series 22 (2), pp. 228-248.

SyKas, P. A. (2006): "Hot Press Printing of Worsted Cloth: A Precursor of Roller Printing», in M.-S. Corcy, C. Douyère-Demeulenaere, and L. Hilaire-Pérez (eds), Les archives de l'invention: écrits, objets et images de l'activité inventive. Le Mirail: CNRS-Université de Toulouse, pp. 101-112.

SyKas, P. A. (2009): «Identifying Printed Textiles in Dress 1740-1890». Available at http://www.dressandtextilespecialists.org.uk/Print\%20Booklet.pdf.

TABELLINI, G. (2010): «Culture and Institutions: Economic Development in the Regions of Europe». Journal of the European Economic Association 8 (4), pp. 677-716.

Tainter, J. A. (2000): «Problem Solving: Complexity, History, Sustainability». Population and Environment 22 (1), pp. 3-41.

Tilly, C. (ed.) (1975): The Formation of National States in Western Europe. Princeton, NJ: Princeton University Press.

Тосн, M. (1993): «Hauling Away in Late Medieval Bavaria: The Economics of Inland Transport in an Agrarian Market». Agricultural History Review 41 (2), pp. 111-123.

Torras, J., and Yun, B. (1999): Consumo, condiciones de vida y comercializacion. Cataluna y Castilla (siglos XVII-XIX). Valladolid: Junta de Castilla y Leon.

Torras, J., and Yun, B. (2003): «Historia del consumo e historia del crecimiento. El consumo de tejidos en España, 1700-1850». Revista de Historia Económica XXI, pp. 17-41.

TRACY, J. D. (2002): Emperor Charles V, Impresario of War: Campaign Strategy, International Finance, and Domestic Politics. Cambridge: Cambridge University Press.

De VRIES, J. (1984): European Urbanization, 1500-1800. London: Methuen.

De Vries, J., and Van Der Woude, A. D. (1997): The First Modern Economy: Success, Failure, and Perseverence of the Dutch Economy, 1500-1815. Cambridge: Cambridge University Press.

URIOL, J. I. (1980): «Los transportes interiores de mercancías en el siglo XVIII y en los primeros años del siglo XIX». Revista de Obras Públicas 127 (3184), pp. 707-714.

Uriol, J. I. (1992): Historia de los caminos de España. Madrid: Colegio de Ingenieros de Caminos Canales y Puertos.

Utanda Moreno, L. (2001-2002): "Comercio y transportes en la comarca madrileña de Las Vegas entre mediados del s. XVIII y comienzos del s. XX». Boletín de la Real Sociedad Geográfica Tomo CXXXVII - CXXXVIII, pp. 341-351.

Valdaliso, J. M., and López, S. (2006): Historia económica de la empresa. Barcelona: Crítica.

Wee, H. Van Der (2002): «The Early Modern Period», in D. Jenkins (ed.), The Cambridge History of Western Textiles. Cambridge: Cambridge University Press, pp. 452-461.

WiLson, C. (1960): «Cloth Production and International Competition in the Seventeenth Century». The Economic History Review, New Series 13 (2), pp. 209-221. 